\title{
Article \\ Structural Equation Modeling (SEM) Analysis of Sequence Variation and Green Plant Regeneration via Anther Culture in Barley
}

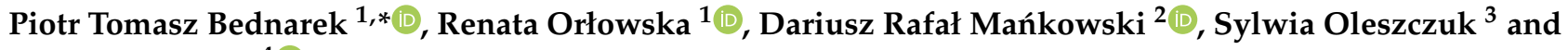 \\ Jacek Zebrowski ${ }^{4}$ \\ 1 Department of Plant Physiology and Biochemistry, Plant Breeding and Acclimatization Institute-National \\ Research Institute, 05-870 Błonie, Poland; r.orlowska@ihar.edu.pl \\ 2 Department of Seed Science and Technology, Plant Breeding and Acclimatization Institute-National \\ Research Institute, 05-870 Błonie, Poland; d.mankowski@ihar.edu.pl \\ 3 Department of Plant Biotechnology and Cytogenetics, Plant Breeding and Acclimatization \\ Institute-National Research Institute, 05-870 Błonie, Poland; s.oleszczuk@ihar.edu.pl \\ 4 Institute of Biology and Biotechnology, University of Rzeszow, 35-959 Rzeszow, Poland; jaze28@interia.pl \\ * Correspondence: p.bednarek@ihar.edu.pl
}

Citation: Bednarek, P.T.; Orłowska, R.; Mańkowski, D.R.; Oleszczuk, S.; Zebrowski, J. Structural Equation Modeling (SEM) Analysis of Sequence Variation and Green Plant Regeneration via Anther Culture in Barley. Cells 2021, 10, 2774. https:// doi.org/10.3390/cells10102774

Academic Editor: Avtar K. Handa

Received: 31 August 2021

Accepted: 12 October 2021

Published: 16 October 202

Publisher's Note: MDPI stays neutral with regard to jurisdictional claims in published maps and institutional affiliations.

Copyright: (c) 2021 by the authors. Licensee MDPI, Basel, Switzerland. This article is an open access article distributed under the terms and conditions of the Creative Commons Attribution (CC BY) license (https:// creativecommons.org/licenses/by/ $4.0 /)$

\begin{abstract}
The process of anther culture involves numerous abiotic stresses required for cellular reprogramming, microspore developmental switch, and plant regeneration. These stresses affect DNA methylation patterns, sequence variation, and the number of green plants regenerated. Recently, in barley (Hordeum vulgare L.), mediation analysis linked DNA methylation changes, copper $\left(\mathrm{Cu}^{2+}\right)$ and silver $\left(\mathrm{Ag}^{+}\right)$ion concentrations, sequence variation, $\beta$-glucans, green plants, and duration of anther culture (Time). Although several models were used to explain particular aspects of the relationships between these factors, a generalized complex model employing all these types of data was not established. In this study, we combined the previously described partial models into a single complex model using the structural equation modeling approach. Based on the evaluated model, we demonstrated that stress conditions (such as starvation and darkness) influence $\beta$-glucans employed by cells for glycolysis and the tricarboxylic acid cycle. Additionally, $\mathrm{Cu}^{2+}$ and $\mathrm{Ag}^{+}$ions affect DNA methylation and induce sequence variation. Moreover, these ions link DNA methylation with green plants. The structural equation model also showed the role of time in relationships between parameters included in the model and influencing plant regeneration via anther culture. Utilization of structural equation modeling may have both scientific and practical implications, as it demonstrates links between biological phenomena (e.g., culture-induced variation, green plant regeneration and biochemical pathways), and provides opportunities for regulating these phenomena for particular biotechnological purposes.
\end{abstract}

Keywords: androgenesis; barley; $\beta$-glucans; copper ions; DNA methylation; DNA sequence; plant regeneration; silver ions

\section{Introduction}

Anther culture involves cold treatment of spikes [1], dark incubation of tissue culture [2], addition of chemicals [3], and many other stress-inducing steps [4] that affect plant regeneration. Cold treatment is necessary for the developmental switch of microspores from the gametophytic to embryogenic fate [5], a process that requires DNA demethylation, followed by de novo methylation [6]. DNA demethylation as, well as de novo methylation, may alter the DNA methylation patterns [7-10], which could lead to DNA mutations [11] and mobile element activation [12,13]. During reprogramming, an increase in cell death and oxidative stress is observed [14]. The equilibrium between reactive oxygen species (ROS)-scavenging and ROS-producing mechanisms governs the level of damage and oxidative stress in the cell $[15,16]$. Low temperature may also alter endogenous ethylene (ET) 
levels, enhancing tolerance to higher ET concentrations [17]. Dark incubation of tissue culture in the presence of mannitol leads to carbon starvation [18], forcing cells to utilize all available carbon resources $[19,20]$. Because photosynthesis cannot be accomplished in the dark, cells attempt to utilize $\beta$-glucans located between the cell wall and cell membrane, the so-called subintinal layer, in many kinds of cereals. In barley (Hordeum vulgare L.), $\beta$-glucans synthase are encoded by the CELLULOSE SYNTHASE-LIKE (CSL) gene family [21]. In cells that undergo fate transition, the so-called subintinal layer usually contains callose ( $\beta$-1,3-glucan) [22]. Callose protects the cell from disruption due to osmotic stress and can be easily utilized by the cell for glycolysis [23,24]. Moreover, glucans also act as antioxidants, thus lowering oxidative stress and affecting the mitochondrial respiratory chain in humans [25]. Moreover, in cultured tobacco cells NADPH-dependent enzymes are involved in glucan-elicited resistance responses, and the inhibition and enhancement of ROS production using NADP ${ }^{+}$and NADPH, respectively [26]. Unfortunately, it is unclear whether $\beta$-glucans lower oxidative stress in plants. However, during the shortage of glucose, glycolysis is disturbed, which affects the tricarboxylic acid cycle (TCA) [27]. Tissue culture is also affected by the presence of ingredients, such as copper $\left(\mathrm{Cu}^{2+}\right)$ and silver $\left(\mathrm{Ag}^{+}\right)$ions. $\mathrm{Cu}^{2+}$ ions participate in the mitochondrial electron transport chain $[28,29]$, photosynthesis and respiration [30,31], ET detection [32], cell wall metabolism [28], and oxidative stress [33]. $\mathrm{Cu}^{2+}$ ions also contribute to hydroxyl radical formation [29] and affect the Krebs cycle at high concentrations [34]. Moreover, $\mathrm{Cu}^{2+}$ ions act as a cofactor for the binding of ET to the ethylene receptor 1 (ETR1) protein [32], and participate in a broad range of biochemical pathways linked with DNA methylation [35]. It was also reported that the higher level of copper concentration in the medium was beneficial for the frequency of green plants regeneration in various in vitro cultures [36,37]. Increasing efficiency in the regeneration of green plants is significant, especially in the androgenesis process, where albinism is one of the major problems reducing the number of obtained plants [38]. Albino regenerants (off type) have an impaired chlorophyll production mechanism [39] and are thus unable to carry out photosynthesis (about albinism see more in [40]). Because copper is involved in chlorophyll biosynthesis [41], plastid division and the transformation of amyloplasts into proplastids, therefore, can affect the number of albino plants [42]. In addition to $\mathrm{Cu}^{2+}$ ions, $\mathrm{Ag}^{+}$ions also affect tissue culture; for example, $\mathrm{Ag}^{+}$ions increase the number of green plants derived via androgenesis [43]. $\mathrm{Cu}^{2+}$ and $\mathrm{Ag}^{+}$ ions are of comparable sizes. Thus, $\mathrm{Ag}^{+}$ions may replace $\mathrm{Cu}^{2+}$ ions [44], for example, in the mitochondrial complex IV [45]. Both ions form complexes with ET [46,47]. Additionally, $\mathrm{Ag}^{+}$ions influence ethylene action, thus inhibiting its receptors [46].

Although abiotic stresses and ingredients used in tissue culture media during anther culture are required for the regeneration of green plants, these stresses alter DNA methylation patterns and induce DNA sequence variation (SV). Recently, we determined the quantitative characteristics of barley regenerants derived by anther culture using methylation-sensitive amplified fragment length polymorphism (metAFLP) molecular markers [9], and mediation analysis of these quantitative characteristics demonstrated that $\mathrm{Cu}^{2+}$ and $\mathrm{Ag}^{+}$ion concentrations in the medium and culture duration affect CG demethylation, leading to DNA mutations [48]. Additionally, mediation analysis of the spectral features of barley regenerants obtained using attenuated total reflection Fourier transform infrared (ATR-FTIR) spectroscopy, which is sensitive to the presence of molecular structures and their molecular environment [49], revealed that $\beta$-glucans, and S-adenosylL-methionine (SAM) participate in DNA methylation, resulting in SV [50]. The ATR-FTIR spectroscopy method has been successfully used for examination of biological material, including plant tissues [51-53]. Finally, using diversity arrays technology sequencing methylation analysis (DArTseqMet) [54] markers and moderation analysis [55], we confirmed that $\mathrm{Cu}^{2+}$ and $\mathrm{Ag}^{+}$ions are involved in green plant regeneration in barley [56]. However, relationships between $\beta$-glucans, DNA methylation patterns, $\mathrm{Cu}^{2+}$ and $\mathrm{Ag}^{+}$ions, $\mathrm{SV}$, green plant (GP) regeneration, and anther culture duration were not evaluated. 
We hypothesized that abiotic stresses acting on barley microspores are somehow sensed by the inner callose layer comprising $\beta$-glucans. Cells utilize $\beta$-glucans as a carbon source under in vitro culture conditions, thus affecting glycolysis and TCA. The presence of $\mathrm{Cu}^{2+}$ and $\mathrm{Ag}^{+}$ions in the medium affects the mitochondrial respiratory chain and the amount of adenosine triphosphate (ATP) needed for the biosynthesis of SAM via the Yang cycle [57-59]. $\mathrm{Cu}^{2+}$ ions can cause oxidative stress, leading to changes in the methylation patterns of DNA, especially cytosines [60]. Moreover, modified bases are subject to repair. If the repair system does not work correctly, modified cytosines act as a source of DNA mutation. We also suspect that $\mathrm{Cu}^{2+}$ and $\mathrm{Ag}^{+}$ions, as well as DNA methylation changes, may be responsible for green plant regeneration, and the tissue culture duration controls DNA methylation changes, SV and green plant regeneration. Such relationships could be predicted using the structural equation modeling (SEM) approach [61], which is widely exploited in psychology [62] but relatively rarely in biology [63] and agriculture [64,65]. The primary goal of SEM is to explain the observed variability in the data set, described by the covariance matrix, with smallest number of parameters of the postulated model for the analyzed process or phenomenon. If the tested model is confirmed using empirical data, then it is possible to estimate the strength of the relationship between the variables included in this model. These relationship strengths accurately represent the cause and effect of the process being studied. SEM, unlike other methods of statistical modeling, allows the inclusion of all interactions and interdependencies that accompany a given process or phenomenon [64]. Utilizing SEM for studying relationships between multiple factors putatively involved in the control of tissue culture-induced variation (TCIV), components of biochemical pathways affected by in vitro anther culture and green plant regeneration is a sophisticated combination of methods allowing better understanding of complex relationships in anther culture. Such knowledge may have practical implications, as it may help to gain control over the number of green plants regenerated via in vitro anther culture and the level of DNA SV in these plants.

In this study, we evaluated the relationships between different factors affecting SV and green plant regeneration via anther culture in barley using the SEM approach.

\section{Materials and Methods}

Data used for current analysis and model generation were based on plant materials evaluation, DNA isolation and metAFLP and DArTSeqMet analysis, as well as the FTIR spectroscopy conducted and described earlier $[48,50,56]$.

Variables used for SEM, their descriptive statistics are given in Table 1, whereas Pearson's linear correlation coefficients in Table 2 (see Results).

Table 1. Descriptive statistics of the analyzed variables and their presence in postulated models (calculated based on data in Table 1).

\begin{tabular}{|c|c|c|c|c|}
\hline \multirow{2}{*}{ Variable } & \multicolumn{4}{|c|}{ Descriptive Statistics } \\
\hline & Mean & Variance & Skewness & Kurtosis \\
\hline$[\mathrm{F} 1010.940]^{1}$ & 0.035 & 0.000 & 0.531 & -0.689 \\
\hline$\left[\mathrm{Cu}^{2+}\right]$ & 4.751 & 17.205 & 0.123 & -1.573 \\
\hline$\left[\mathrm{Ag}^{+}\right]$ & 20.286 & 667.546 & 0.900 & -1.129 \\
\hline [DNM-DM] & 0.794 & 6.089 & -0.804 & -0.048 \\
\hline [CG_DMV] & 0.391 & 0.056 & 0.170 & 0.219 \\
\hline [CHG_DMV] & 0.940 & 0.098 & -2.393 & 5.433 \\
\hline [SV] & 3.952 & 9.585 & 2.849 & 7.049 \\
\hline [GP] & 1.123 & 0.715 & 0.835 & -0.424 \\
\hline [Time] & 27.800 & 35.988 & 0.057 & -1.657 \\
\hline
\end{tabular}

${ }^{1}$ F1010.940: the area integrated absorbance for spectral ranges between 1010 and $940 \mathrm{~cm}^{-1}$ evaluated by attenuated total reflection Fourier transform infrared (ATR-FTIR) spectroscopy. $\mathrm{Cu}^{2+}$ and $\mathrm{Ag}^{+}$are copper and silver ion concentrations; DNM, de novo methylation; DM: demethylation; DNM-DM: changes in methylation; CG_DMV and CHG_DMV: demethylation of the CG and CHG contexts; SV: sequence variation; GP: number of green plants regenerated per 100 anthers. Square brackets are given to indicate that the respective parameters are variables in SEM. 
Table 2. Pearson's linear correlation coefficients for analyzed variables.

\begin{tabular}{|c|c|c|c|c|c|c|c|c|c|}
\hline Variable & [F1010.940 $^{1}$ & {$\left[\mathrm{Cu}^{2+}\right]$} & {$\left[\mathrm{Ag}^{+}\right]$} & [DNM_DM] & [CG_DMV] & [CHG_DMV] & [SV] & [GP] & {$[\mathrm{T}]$} \\
\hline [F1010.940] & 1.000 & & & & & & & & \\
\hline$\left[\mathrm{Cu}^{2+}\right]$ & $0.338 a^{*}$ & 1.000 & & & & & & & \\
\hline$\left[\mathrm{Ag}^{+}\right]$ & -0.017 & -0.107 & 1.000 & & & & & & \\
\hline [DNM_DM] & -0.128 & $0.476^{* *}$ & 0.166 & 1.000 & & & & & \\
\hline [CG DMV] & -0.157 & -0.055 & -0.208 & -0.023 & 1.000 & & & & \\
\hline [CHG_DMV] & $-0.405 *$ & $-0.438^{* *}$ & $-0.508^{* *}$ & -0.231 & 0.590 ** & 1.000 & & & \\
\hline$[\mathrm{SV}]$ & 0.472 ** & $0.418 *$ & 0.478 ** & 0.080 & -0.391 * & $-0.887^{* *}$ & 1.000 & & \\
\hline [GP] & 0.050 & 0.347 * & 0.157 & 0.210 & -0.315 & -0.251 & 0.240 & 1.000 & \\
\hline [Time] & -0.079 & -0.002 & 0.160 & 0.114 & $0.593^{* *}$ & 0.306 & -0.252 & -0.138 & 1.000 \\
\hline
\end{tabular}

To eliminate constants from the structural equation model, the difference between observation and mean value for variables was used instead of raw data.

The structural equation model was implemented in IBM SPSS ${ }^{\circledR}$ Amos $^{\text {TM }} 20$ [66] computer software. The maximum likelihood (ML) estimation with the Levenberg-Marquardt iteration method was used to optimize the parameters of postulated models [67-69].

\section{Results}

Molecular and phenotypic data as well as the results of mediation analysis presented in our earlier study [50] were used here to create a generalized model predicting essential relationships between selected genetic and biochemical features and $\mathrm{Cu}^{2+}$ and $\mathrm{Ag}^{+}$ions concentrations in barley (Hordeum vulgare L.) anther cultures.

\subsection{Characterization of Input Data}

Construction of the structural equation model was based on nine variables evaluated employing metAFLP characteristics, DArTseqMet marker-based methylation changes, ATRFTIR spectroscopy, $\mathrm{Cu}^{2+}$ and $\mathrm{Ag}^{+}$ion concentrations and Time. The descriptive statistics of the analyzed variables, including mean, variance, skewness and kurtosis are presented in Table 1.

All of the analyzed variables were quantitative and met the conditions set out and the Lindeberg-Lévy theorem [70]. It can, therefore, be assumed that the distribution of these variables is asymptotically convergent with the theoretical normal distribution. Among these variables, CHG_DMV and SV showed relatively high skewness and kurtosis in the analyzed random sample.

Kenny [71] indicated that variables with non-normal distribution, especially those with high kurtosis, inflate the chi-square and absolute measures of fit values [72]. Moreover, the relatively small sample size $(n=35)$ was disadvantageous, as it may falsely result in non-significant chi-square statistics [73]. Therefore, the chi-square test was used only as an information criterion [74] and was not used to determine the correctness of the model. Instead, the correctness of the model should be evaluated using numerous model fit measures.

A wide range of fit measures can be used to assess the goodness of fit of a model. To interpret the fitness of the model, all possible limitations resulting from the specificity of the data and the model itself were taken into account. For example, [73] showed that some goodness-to-fit indices are relatively stable with small sample sizes, whereas others such as root mean square error of approximation (RMSEA) and standardized root mean square residual (SRMR), increase with smaller sample sizes. Additionally, [71] suggested that small sample size can be used for simple models and models without latent variables. Parsimonious fit measures such as parsimonious normed fit index (PNFI) and parsimonious comparative fit index (PCFI) include in their construction an element of model complexity. These measures are used when comparing models with different degrees of freedom (df). The higher the value of these indices, the better the model [75,76].

SEM allows creating a statistical description of complex causal relationships. Compared with other commonly used methods (such as regression analysis and Write's path 
analysis), SEM permits the inclusion of more complex relationships between variables, including those with exogenous variables, in the model. The correlation coefficient analysis allows the evaluation of the occurrence and complexity of the relationship within the studied process or phenomenon. Pearson linear correlation coefficients (Table 2) revealed correlations between the analyzed traits, indicating a complex relationship within the analyzed data.

\subsubsection{Model Specification and Estimation}

SEM revealed relationships between all variables included in Table 1. The postulated model contained two exogenous variables (F1010.940 and Time), seven endogenous variables $\left(\mathrm{Cu}^{2+}, \mathrm{Ag}^{+}, \mathrm{CHG} \_\mathrm{DMV}, \mathrm{CG} \_\mathrm{DMV}, \mathrm{DNM}-\mathrm{DM}, \mathrm{SV}\right.$ and GP) with seven random errors, one covariance effect and 16 non-recursive relations (Figure 1).

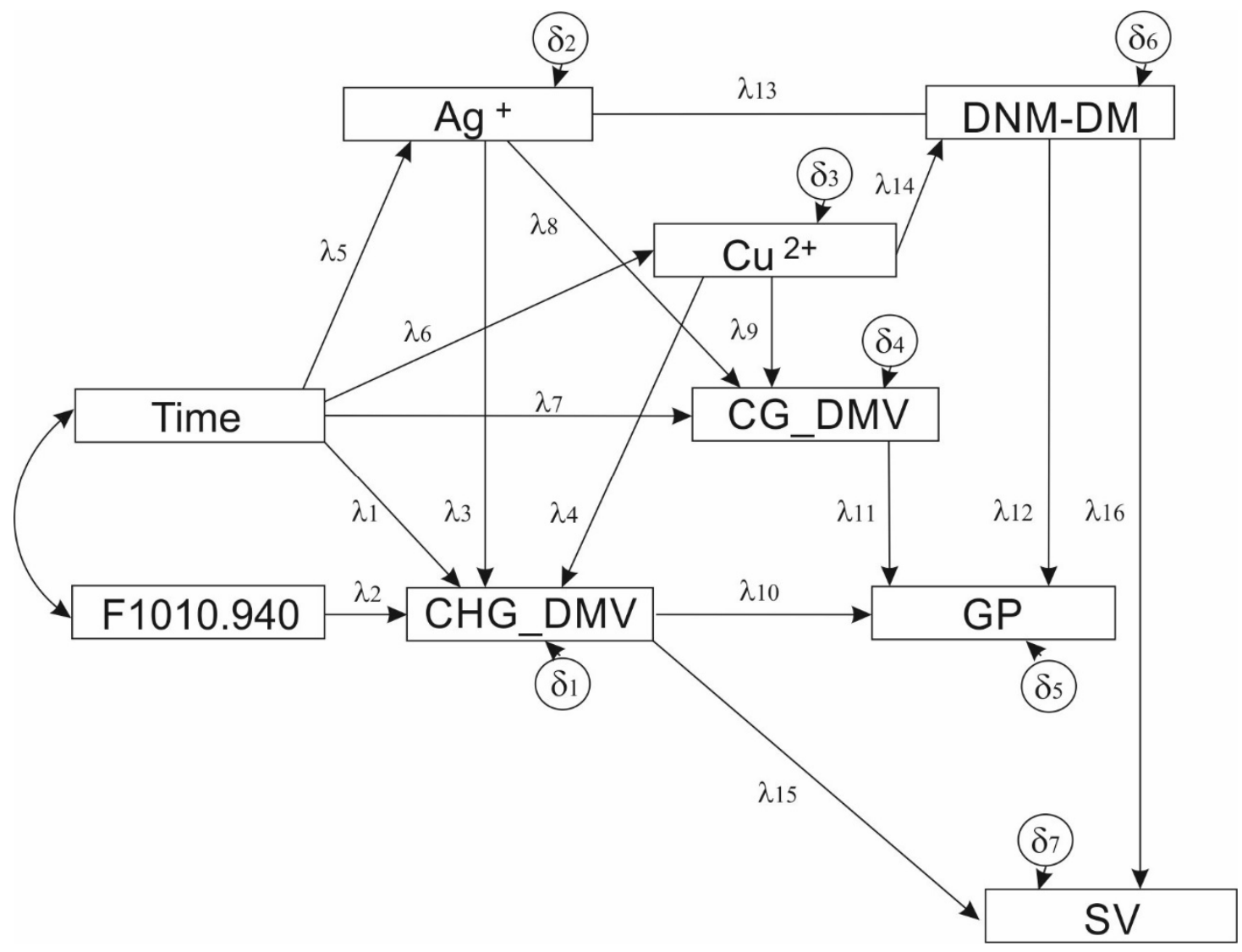

Figure 1. The path diagram is a graphical representation of the structural equation model. Rectangles represent observable endo- and exogenous variables, whereas circles are random errors for endogenous variables (denoted by delta symbols). One-way arrows illustrate causal relationships between variables. Path coefficients are marked by lambda parameters. The semicircular bidirectional arrow represents the presence of covariance between exogenous variables in the model. Time represents the duration of anther culture; CHG_DMV and CG_DMV represent the DNA demethylation of the CHG and CG sequence contexts, respectively, determined using metAFLP markers [9,48]; SV represents sequence variation evaluated using the metAFLP approach; DNM-DM is the difference between de novo methylation and DNA demethylation, evaluated using the DArTseqMet approach [54,56]; GP is the number of green plants regenerated per 100 anthers via in vitro anther culture of barley [43]; $\mathrm{Cu}^{2+}$ and $\mathrm{Ag}^{+}$represent ion concentrations present in the tissue culture medium [9,43]. The F1010.940 is the ATR-FTIR spectral range assigned to $\beta$-glucans $\left(1010-940 \mathrm{~cm}^{-1}\right)$ [50].

\subsubsection{Model Description}

The structural equation model (SEM) illustrates (Figure 1) the role of copper and silver ions added to the in vitro induction medium during barley plant regeneration via anther culture Copper ions influence both SV and GP. Based on the model, copper ions affect 
CHG_DMV. The CHG_DMV directly affects SV and GP. Time of anther culture also plays an essential role in the action of the ion. Silver ions directly influence CHG_DMV, and the DNM-DM is involved in GPs. Moreover, DNM-DM may also influence SV. The action of silver ions is controlled by Time of anther culture. The F1010.940 is to be linked to the CHG_DMV.

\subsubsection{Model Matching}

The quality of the structural equation model is assessed by analyzing the fit of the relationship system described by the postulated model to the mutual relationship system within the data derived from the real assessment of a given process or phenomenon. Various fit statistics are used for this purpose.

The tested model met all the convergence criteria. The fit statistics (Table 3) were proper. The chi-square statistic indicated that the postulated model satisfactorily confirmed the empirical data.

Table 3. Summary of the analyzed structural equation model.

\begin{tabular}{cc}
\hline Parameter & Postulated Model \\
\hline Degrees of freedom (df) & 19 \\
Chi-square & 21.125 \\
$p$-value & 0.330 \\
Root Mean Squares Residuals (RMR) & 2.836 \\
Standardized Root Mean Squares Residuals (SRMR) & 0.134 \\
Goodness-of-Fit Index (GFI) & 0.862 \\
Adjusted Goodness-of-Fit Index (AGFI) & 0.673 \\
Normed Fit Index (NFI) & 0.647 \\
Relative Fit Index (RFI) & 0.331 \\
Incremental Fit Index (IFI) & 0.948 \\
Non-Normed Fit Index (NNFI) & 0.831 \\
Comparative Fit Index (CFI) & 0.911 \\
Parsimonious Normed Fit Index (PNFI) & 0.341 \\
Parsimonious Comparative Fit Index (PCFI) & 0.481 \\
Root Mean Square Error of Approximation (RMSEA) & 0.057 \\
\hline
\end{tabular}

The SRMR value was relatively low but failed to meet the criterion defined by $\mathrm{Hu}$ and Bentler [77,78]. In multiple regression analysis, the goodness-of-fit index (GFI) and adjusted goodness-of-fit index (AGFI) can be interpreted analogously to the coefficient of determination [79]. Values of both AGFI and GFI were high, and GFI was close to the lowest limit (0.9), implying that the postulated model describes approximately $90 \%$ of the variability observed in the dataset. The normed fit index (NFI) and relative fit index (RFI) did not exceed the limit reported in the literature $(0.95)[77,78]$. The same was true for the incremental fit index (IFI), non-normed fit index (NNFI) and comparative fit index (CFI), but not for NNFI. However, applying the rule described by MacCallum and colleagues [80], obtained RMSEA results testified that the postulated model showed a good fit.

\subsubsection{Estimation of Model Parameters}

After confirming that the postulated model is correct (i.e., it describes the system of dependencies within empirical data), the estimated values of the structural equation model parameters were used for a detailed description of the type and nature of causal relationships.

The values of individual path coefficients were estimated. Some of these coefficients were not statistically significant; however, their removal resulted in a substantial reduction in the quality of matching between the postulated model and the empirical data. Therefore, we decided to retain all the paths in the model (Table 4). 
Table 4. Path coefficients, variances and covariances for the analyzed model.

\begin{tabular}{|c|c|c|c|c|c|c|c|}
\hline Parameter & & Effect & & Estimate $(b)$ & Standard Error & Test Statistic & $\begin{array}{c}\text { Standardized } \\
\text { Estimate }(\beta)\end{array}$ \\
\hline \multicolumn{8}{|c|}{ Path coefficients } \\
\hline$\lambda_{1}$ & [Time] & $\rightarrow$ & [CHG_DMV] & 0.014 & 0.005 & $2.641 * *$ & 0.284 \\
\hline$\lambda_{2}$ & [F1010.940] & $\rightarrow$ & [CHG_DMV] & -6.230 & 5.127 & -1.215 & -0.139 \\
\hline$\lambda_{3}$ & {$\left[\mathrm{Ag}^{+}\right]$} & $\rightarrow$ & [CHG_DMV] & -0.007 & 0.001 & $-6.508^{* *}$ & -0.695 \\
\hline$\lambda_{4}$ & {$\left[\mathrm{Cu}^{2+}\right]$} & $\rightarrow$ & [CHG_DMV] & -0.037 & 0.009 & $-4.180 * *$ & -0.481 \\
\hline$\lambda_{5}$ & [Time] & $\rightarrow$ & {$\left[\mathrm{Ag}^{+}\right]$} & 0.800 & 0.834 & 0.959 & 0.173 \\
\hline$\lambda_{6}$ & [Time] & $\rightarrow$ & {$\left[\mathrm{Cu}^{2+}\right]$} & -0.023 & 0.127 & -0.179 & -0.036 \\
\hline$\lambda_{7}$ & [Time] & $\rightarrow$ & [CG_DMV] & 0.018 & 0.005 & $3.555 * *$ & 0.592 \\
\hline$\lambda_{8}$ & {$\left[\mathrm{Ag}^{+}\right]$} & $\rightarrow$ & [CG_DMV] & -0.003 & 0.001 & $-2.404 *$ & -0.402 \\
\hline$\lambda_{9}$ & {$\left[\mathrm{Cu}^{2+}\right]$} & $\rightarrow$ & [CG_DMV] & -0.009 & 0.009 & -1.011 & -0.179 \\
\hline$\lambda_{10}$ & [CHG_DMV] & $\rightarrow$ & {$[\mathrm{GP}]$} & 0.055 & 0.676 & 0.082 & 0.019 \\
\hline$\lambda_{11}$ & [CG_DMV] & $\rightarrow$ & [GP] & -2.596 & 0.953 & $-2.723^{* *}$ & -0.563 \\
\hline$\lambda_{12}$ & [DNM_DM] & $\rightarrow$ & [GP] & 0.046 & 0.068 & 0.684 & 0.141 \\
\hline$\lambda_{13}$ & {$\left[\mathrm{Ag}^{+}\right]$} & $\rightarrow$ & [DNM-DM] & 0.021 & 0.013 & 1.586 & 0.220 \\
\hline$\lambda_{14}$ & {$\left[\mathrm{Cu}^{2+}\right]$} & $\rightarrow$ & [DNM-DM] & 0.454 & 0.109 & $4.161^{* *}$ & 0.646 \\
\hline$\lambda_{15}$ & [CHG_DMV] & $\rightarrow$ & [SV] & -9.803 & 1.047 & $-9.366^{* *}$ & -0.985 \\
\hline$\lambda_{16}$ & [DNM_DM] & $\rightarrow$ & [SV] & -0.200 & 0.106 & -1.880 & 0.141 \\
\hline \multicolumn{8}{|c|}{ Covariances } \\
\hline$\varphi 1$ & [F1010.940] & $\leftrightarrow$ & [Time] & 0.002 & 0.007 & 0.347 & 0.074 \\
\hline \multicolumn{8}{|c|}{ Variances } \\
\hline$\delta_{1}$ & & & & 0.018 & 0.005 & $3.346^{* *}$ & \\
\hline$\delta_{2}$ & & & & 616.775 & 151.285 & $4.077^{* *}$ & \\
\hline$\delta_{3}$ & & & & 11.636 & 3.407 & $3.415^{* *}$ & \\
\hline$\delta_{4}$ & & & & 0.015 & 0.005 & $3.018 * *$ & \\
\hline$\delta_{5}$ & & & & 0.396 & 0.124 & $3.199 * *$ & \\
\hline$\delta_{6}$ & & & & 3.083 & 0.930 & $3.313 * *$ & \\
\hline$\delta_{7}$ & & & & 1.120 & 0.328 & $3.418 * *$ & \\
\hline [Time] & & & & 29.723 & 7.845 & $3.789 * *$ & \\
\hline [F1010.940] & & & & 0.000 & 0.000 & $3.015 * *$ & \\
\hline
\end{tabular}

* — significant at $p<0.05 ;{ }^{* *}$ —significant at $p<0.01$.

Absolute values of the standardized path coefficients explaining the relationships between various variables were calculated. The highest value was obtained for the relationship between CHG_DMV and SV, followed by that between $\mathrm{Ag}^{+}$and CHG_DMV, $\mathrm{Cu}^{2+}$ and DNM_DM, Time and CG_DMV, CG_DMV and GP, $\mathrm{Cu}^{2+}$ and CHG_DMV and lastly $\mathrm{Ag}^{+}$and CG_DMV.

No significant covariance was found between exogenous variables. The estimated variances for random components $(\delta 1-\delta 7)$ and variances of exogenous variables were significantly different from zero.

The significance of model parameters expressing direct, indirect and total effects on standardized coefficients is summarized in Table 5. The CHG_DMV variable showed the highest dependence on $\mathrm{Ag}^{+}(\beta=-0.695)$ and $\mathrm{Cu}^{2+}(\beta=-0.481)$ ions, and these were direct effects. The SV variable showed the greatest dependence on CHG_DMV $(\beta=-0.985)$, an immediate (direct) effect, followed by $\mathrm{Ag}^{+}(\beta=0.644)$ and $\mathrm{Cu}^{2+}(\beta=0.356)$ ions, which represented indirect effects. The GP variable showed the highest dependence on CG_DMV ( $\beta=-0.563$; direct effect), followed by $\mathrm{Ag}^{+}$ions $(\beta=0.245$; indirect effect). 
Table 5. Direct, indirect and total effects for the analyzed model.

\begin{tabular}{|c|c|c|c|c|c|c|c|c|}
\hline & \multirow[b]{2}{*}{ Effect } & & \multicolumn{3}{|c|}{ Estimates $(b)$} & \multicolumn{3}{|c|}{ Standardized Estimates $(\beta)$} \\
\hline & & & $\begin{array}{l}\text { Direct } \\
\text { Effect }\end{array}$ & $\begin{array}{l}\text { Indirect } \\
\text { Effects }\end{array}$ & $\begin{array}{c}\text { Total } \\
\text { Effects }\end{array}$ & $\begin{array}{l}\text { Direct } \\
\text { Effect }\end{array}$ & $\begin{array}{l}\text { Indirect } \\
\text { Effects }\end{array}$ & $\begin{array}{c}\text { Total } \\
\text { Effects }\end{array}$ \\
\hline \multicolumn{9}{|c|}{ [CHG_DMV] } \\
\hline [Time] & $\rightarrow$ & [CHG_DMV] & 0.014 & -0.005 & 0.009 & 0.284 & -0.103 & 0.181 \\
\hline [F1010.940] & $\rightarrow$ & [CHG_DMV] & -6.230 & - & -6.230 & -0.139 & - & -0.139 \\
\hline$\left[\mathrm{Ag}^{+}\right]$ & $\rightarrow$ & [CHG_DMV] & 0.007 & - & 0.007 & -0.695 & - & -0.695 \\
\hline$\left[\mathrm{Cu}^{2+}\right]$ & $\rightarrow$ & [CHG_DMV] & -0.037 & - & -0.037 & -0.481 & - & -0.481 \\
\hline \multicolumn{9}{|c|}{$\left[\mathrm{Ag}^{+}\right]$} \\
\hline [Time] & $\rightarrow$ & {$\left[\mathrm{Ag}^{+}\right]$} & 0.800 & - & 0.800 & 0.173 & - & 0.173 \\
\hline \multicolumn{9}{|c|}{$\left[\mathrm{Cu}^{2+}\right]$} \\
\hline [Time] & $\rightarrow$ & {$\left[\mathrm{Cu}^{2+}\right]$} & -0.023 & - & -0.023 & -0.036 & - & -0.036 \\
\hline \multicolumn{9}{|c|}{ [SV] } \\
\hline [CHG_DMV] & $\rightarrow$ & [SV] & -9.803 & - & -9.803 & -0.985 & - & -0.985 \\
\hline [Time] & $\rightarrow$ & [SV] & - & -0.088 & -0.088 & - & -0.181 & -0.181 \\
\hline [F1010.940] & $\rightarrow$ & [SV] & - & 61.073 & 61.073 & - & 0.137 & 0.137 \\
\hline$\left[\mathrm{Ag}^{+}\right]$ & $\rightarrow$ & [SV] & - & 0.067 & 0.067 & - & 0.644 & 0.644 \\
\hline$\left[\mathrm{Cu}^{2+}\right]$ & $\rightarrow$ & [SV] & - & 0.275 & 0.275 & - & 0.356 & 0.356 \\
\hline [DNM_DM] & $\rightarrow$ & [SV] & -0.200 & - & -0.200 & -0.182 & - & -0.182 \\
\hline \multicolumn{9}{|c|}{ [GP] } \\
\hline [CHG_DMV] & $\rightarrow$ & [GP] & 0.055 & - & 0.055 & 0.019 & - & 0.019 \\
\hline [Time] & $\rightarrow$ & [GP] & - & -0.042 & -0.042 & - & -0.292 & -0.292 \\
\hline [F1010.940] & $\rightarrow$ & [GP] & - & -0.344 & -0.344 & - & -0.003 & -0.003 \\
\hline$\left[\mathrm{Ag}^{+}\right]$ & $\rightarrow$ & [GP] & - & 0.008 & 0.008 & - & 0.245 & 0.245 \\
\hline$\left[\mathrm{Cu}^{2+}\right]$ & $\rightarrow$ & [GP] & - & 0.042 & 0.042 & - & 0.183 & 0.183 \\
\hline [CG_DMV] & $\rightarrow$ & [GP] & -2.596 & - & -2.596 & -0.563 & - & -0.563 \\
\hline [DNM_DM] & $\rightarrow$ & [GP] & 0.046 & - & 0.046 & 0.141 & - & 0.141 \\
\hline \multicolumn{9}{|c|}{ [CG_DMV] } \\
\hline$\left[\mathrm{Ag}^{+}\right]$ & $\rightarrow$ & [CG_DMV] & -0.003 & - & -0.003 & -0.402 & - & -0.402 \\
\hline$\left[\mathrm{Cu}^{2+}\right]$ & $\rightarrow$ & [CG_DMV] & -0.009 & - & -0.009 & -0.179 & - & -0.179 \\
\hline [Time] & $\rightarrow$ & [CG_DMV] & 0.017 & - & 0.017 & 0.591 & - & 0.529 \\
\hline \multicolumn{9}{|c|}{ [DNM_DM] } \\
\hline$\left[\mathrm{Ag}^{+}\right]$ & $\rightarrow$ & [DNM_DM] & 0.021 & - & 0.021 & 0.220 & - & 0.220 \\
\hline$\left[\mathrm{Cu}^{2+}\right]$ & $\rightarrow$ & [DNM_DM] & 0.454 & - & 0.454 & 0.646 & - & 0.646 \\
\hline [Time] & $\rightarrow$ & [DNM_DM] & - & 0.006 & 0.006 & - & 0.015 & 0.015 \\
\hline
\end{tabular}

The relationship of the CG_DMV variable with Time $(\beta=0.591)$ and $\mathrm{Ag}^{+}$ion concentration $(\beta=-0.402)$, which are both direct effects, showed the greatest weight. The DNM_DM variable depended the most on $\mathrm{Cu}^{2+}(\beta=0.646)$ and $\operatorname{Ag}^{+}(\beta=0.220)$ ion concentrations (direct effects).

\section{Discussion}

The addition of $\mathrm{Cu}^{2+}$ and $\mathrm{Ag}^{+}$ions to the induction and regeneration medium influences plant regeneration via anther culture. The process of tissue culture is predisposed to SV [48] because of changes in DNA methylation patterns [56]. $\mathrm{Cu}^{2+}$ and $\mathrm{Ag}^{+}$ions affect the mitochondrial complex IV [81,82] and the functioning of the Yang cycle [58] (and consequently SAM production). $\mathrm{Cu}^{2+}$ ions also induce mutations in $\mathrm{CG}$ and $\mathrm{CHG}$ sequence contexts [50,56] because of oxidative stress-triggered modification of $5 \mathrm{mC}$ [60]. However, tissue culture-induced SV probably starts much earlier. The presence of mannitol in the culture medium causes starvation stress. Under this condition, $\beta$-glucans, which are present between the cell wall [50] and cell membrane of embryogenic microspores [22], 
are probably utilized as a source of glucose [48] for the production of acetyl-coenzyme A, which is required for the Krebs cycle [83]. Additionally, DNA methylation pattern changes induced during the gametophytic to sporophytic switch [5,84], as well as $\mathrm{Cu}^{2+}$ and $\mathrm{Ag}^{+}$ ion concentrations in the culture medium, determine the number of green plants regenerated via anther culture. Finally, our model also assumed that Time influences SV and GP. Although the link between tissue culture-induced SV and green plant regeneration was not yet established, some elements of such a model had been published previously $[48,50,56]$, which were linked using the SEM approach in this study.

According to the structural equation model, $\beta$-glucans (F1010.940 FTIR spectral range) and CHG_DNMV negatively influenced CHG_DMV and SV, respectively. We failed to include the F710.690 FTIR spectral range (preliminarily assigned to SAM) into the structural equation model. This could be explained by the relatively small sample size and low cellular SAM concentration $(<100 \mathrm{mM})$, which is technically challenging to measure [85]. Fluctuations in SAM concentration may not be sufficient to be significant in a model including many variables under small sample size conditions. However, under starvation conditions, the concentration of SAM increases because of the universal energy-sensing regulator Snf1, which is the yeast (Saccharomyces cerevisiae) ortholog of AMP-activated protein kinase (AMPK) [86].

Effects of $\mathrm{Cu}^{2+}$ and $\mathrm{Ag}^{+}$ion concentrations on CHG_DMV and Time were less pronounced than those of $\beta$-glucans. Thus, demethylation of the CHG context is not under the robust control of metal ions but is influenced by $\beta$-glucans and SV. The model also assumes that Time influences CG_DMV via the action of $\mathrm{Cu}^{2+}$ ions. However, the effects describing this relation are not very strong. The effect of $\mathrm{Ag}^{+}$ions, (acting as a mediator), on Time and CG_DMV was much more pronounced than that of $\mathrm{Cu}^{2+}$ ions. This is in agreement with the fact that $\mathrm{Ag}^{+}$ions may replace $\mathrm{Cu}^{2+}$ ions, for example, in the mitochondrial complex IV, which affects the methionine cycle. Interestingly, in contrast to our results of mediation analysis [50], changes in CG_DMV did not contribute to SV.

All of the relationships that contributed to SV were based on metAFLP characteristics and did not seem to be linked to GP. However, by using DArTseqMet markers, we showed that the difference between de novo methylation and DNA demethylation (DNM-DM), influences SV. Moreover, the DNM-DM variable was affected much more by $\mathrm{Cu}^{2+}$ ions than by $\mathrm{Ag}^{+}$ions. The model predicts that the number of green plants is under the limited control of the DNM-DM variable. Thus, the model presented in this study can explain the SV and is congruent with the role of DNA methylation in SV. We assumed that CHG_DMV rather than CG_DMV participates in SV. However, further investigation is needed to understand whether SV is mainly caused by point mutations or transposable elements. It should be stressed that CHG_DMV only slightly affected GP. This suggests that green plant regeneration is relatively independent of changes in DNA methylation patterns due to anther culture.

It must be emphasized that the model presented in this study might not be able to identify all the relationships affecting SV and GP, possibly because of the limitations of FTIR spectroscopy, non-normal distribution of some variables and/or small sample size. Additional factors need to be incorporated into the model to link these phenomena.

It is always important to question whether the results of SEM analysis are reliable. Based on the analysis of the obtained goodness-of-fit coefficients (Table 4), we conclude that the postulated model is correct and adequately describes the complex relationships between the analyzed variables. The presented model indicates that by manipulating $\mathrm{Cu}^{2+}$ and $\mathrm{Ag}^{+}$ion concentrations, we can predict the biochemical factors that induce $\mathrm{SV}$ and to some extent increase the GP. We also demonstrated that the callose layer is a crucial participant in the model under varying $\mathrm{Cu}^{2+}$ and $\mathrm{Ag}^{+}$concentrations. It would be of value to test whether there is a correlation between the amount of callose present in embryogenic microspore culture and the number of regenerated plants. If so, the presence of callose could be used as an indicator of the capacity of microspores to switch from the gametophytic to sporophytic fate. Callose could also be used to identify genotypes 
suitable for anther-dependent plant regeneration. Thus, understanding the relationships that influence sequence (or total tissue culture-induced) variation and GP is of practical value to plant breeders and scientists working on tissue culture.

Possibly the most important outcome of the structural equation model is the opportunity to predict the level of outcomes (start and end of the path, see Table 5) if the model parameters (independent variables: start of the path) are changed, thus analyzing direct effects. For example, in this study, an increase in F1010.940 by one unit caused a reduction in CHG_DMV by 6.23 units, whereas a reduction in CHG_DMV decreased the SV by 9.8 units. This implies that $\mathrm{Cu}^{2+}$ ions have a limited influence on CHG_DMV, as increasing the $\mathrm{Cu}^{2+}$ ion concentration by one unit decreased CHG_DMV by 0.037 units. Thus, the model predicts that when $\beta$-glucans act as the source of carbon, the larger the subintinal callose layer (under starvation conditions), the lower the CHG_DMV and SV. Furthermore, the role of Time is also limited, as an increase in its value by one unit increased CHG_DMV only by 0.014 units.

Detailed analysis of estimates presented in Table 5 enables the analysis of the paths of influence of individual variables. For example, Time directly influenced $\mathrm{Ag}^{+}$ions $(b=0.800)$, implying that an increase in Time by one unit acts as though the $\mathrm{Ag}^{+}$ion concentration increased by 0.8 units); similarly, an increase in Time by one unit acts as if $\mathrm{Cu}^{2+}$ ion concentration decreased by 0.023 units, and increased CHG_DMV and CG_DMV by 0.014 and 0.017 units, respectively. Additionally, Time influenced CHG_DMV $(b=-0.005)$ indirectly through $\mathrm{Ag}^{+}$and $\mathrm{Cu}^{2+}$ ions, GP $(b=-0.042)$ via CHG_DMV and CG_DMV, and SV $(b=-0.088)$ via CHG_DMV. Similarly, the $\mathrm{Ag}^{+}$ions directly influenced CHG_DMV $(b=0.007)$ and CG_DMV $(b=-0.003)$, but indirectly influenced GP $(b=0.008)$ through CHG_DMV and CG_DMV and similarly SV $(b=0.067)$ via CHG_DMV. $\mathrm{Cu}^{2+}$ ions were characterized by similar paths of dependence. $\mathrm{Cu}^{2+}$ ions directly affected CHG_DMV $(b=-0.037)$ and CG_DMV $(b=-0.009)$ but indirectly influenced GP $(b=0.042)$ and SV $(b=0.275)$ via CHG_DMV and CG_DMV, respectively. Investigating the individual paths of dependence allows us to characterize the changes taking place in the causal model described, if the values of causal variables, such as Time, $\mathrm{Ag}^{+}$or $\mathrm{Cu}^{2+}$ show any change.

While SV was evaluated using metAFLP markers [48,50], GP was examined using MSAP markers [56]. The two marker systems are based on distinct marker platforms utilizing different endonucleases. The metAFLP is based on KpnI and Acc65I isoschizomers, whereas the MSAP approach and the variant involving the DArTseqMet approach are based on HpaII and MspI endonucleases. Additionally, the metAFLP and DArTseqMet methods recognize distinct DNA methylation patterns; while metAFLP can distinguish between methylation changes affecting $\mathrm{CHH}, \mathrm{CHG}$ and CG contexts, DArTseqMet can capture only CHG and CG alterations. Moreover, marker systems recognize different restriction sites. Genetic mapping in cereals demonstrated that many AFLP markers based on the EcoRI endonuclease mapped to genomic regions other than those generated using PstI [87]. Although undocumented, we speculate that KpnI-Acc65I and HpaII-MspI endonuclease pairs will generate markers with non-random distribution along the chromosomes, thus potentially mapping to different genomic regions. Thus, the two marker systems may identify distinct phenomena, similar to the models depicting SV $[48,50]$ and green plant regeneration [56]. Implementation of distinct marker systems in combination with FTIR spectroscopy will be highly valuable for evaluating relationships between multiple factors affecting tissue culture and for predicting the roles of these factors in SV and green plant regeneration.

\section{Conclusions}

We evaluated the structural equation model describing complex relationships between different factors including DNA methylation changes, $\mathrm{SV}, \beta$-glucans, $\mathrm{Cu}^{2+}$ and $\mathrm{Ag}^{+}$ions, Time and GP. The model was constructed on theoretical bases concerning DNA methylation changes, sources of DNA mutations, the effect of $\mathrm{Cu}^{2+}$ and $\mathrm{Ag}^{+}$ion concentrations on DNA methylation and GP. The theoretical background was also supported by our moderation 
and mediation analysis, partly linking the variables. Although the structural equation model was evaluated based on a relatively small sample size (because of experimental limitations), analysis of the model using a wide range of measures of fit suggests that the model is reliable. Nevertheless, the use of this model on larger sample sizes and different cereal species is required to verify its general application in anther culture-derived regenerants. The presented model predicts the outcome of a change in tissue culture conditions.

Author Contributions: Conceptualization, P.T.B.; methodology, P.T.B., R.O. and J.Z.; investigation, R.O., S.O., D.R.M. and J.Z.; writing—original draft preparation, P.T.B., R.O., D.R.M. and J.Z.; writingreview and editing, P.T.B., R.O., D.R.M., S.O. and J.Z.; visualization, P.T.B. and R.O.; supervision, P.T.B.; project administration, P.T.B. and R.O.; funding acquisition, P.T.B. and R.O. All authors have read and agreed to the published version of the manuscript.

Funding: This research was funded by the MINISTRY OF AGRICULTURE AND RURAL DEVELOPMENT (Poland), grant number HORhn-801-PB-22/15-18, and by the NATIONAL SCIENCE CENTRE (Poland), grant MINIATURA 2 number 2018/02/X/NZ9/02042.

Institutional Review Board Statement: Not applicable.

Informed Consent Statement: Not applicable.

Data Availability Statement: Not applicable.

Conflicts of Interest: The authors declare no conflict of interest. The funders had no role in the design of the study; in the collection, analyses, or interpretation of data; in the writing of the manuscript, or in the decision to publish the results.

$\begin{array}{ll}\text { Abbreviations } \\ \text { AGFI } & \text { Adjusted Goodness-of-Fit Index } \\ \text { AMPK } & \text { AMP-Activated Protein Kinase } \\ \text { ATP } & \text { Adenosine Triphosphate } \\ \text { ATR-FTIR } & \text { Attenuated Total Reflection Fourier Transform Infrared spectroscopy } \\ \text { CFI } & \text { Comparative Fit Index } \\ \text { DArTseqMet } & \text { Diversity Arrays Technology Sequencing Methylation Analysis } \\ \text { DM } & \text { Demethylation } \\ \text { DNM } & \text { De Novo methylation } \\ \text { ET } & \text { Endogenous ethylene } \\ \text { ETR1 } & \text { Ethylene receptor1 } \\ \text { GFI } & \text { Goodness-of-Fit Index } \\ \text { GP } & \text { Green Plant } \\ \text { IFI } & \text { Incremental Fit Index } \\ \text { metAFLP } & \text { Methylation-Sensitive Amplified Fragment Length Polymorphism } \\ \text { ML } & \text { Maximum Likelihood } \\ \text { MSAP } & \text { Methylation Sensitive Amplification Polymorphism } \\ \text { NFI } & \text { Normed Fit Index } \\ \text { NNFI } & \text { Non-Normed Fit Index } \\ \text { PCFI } & \text { Parsimonious Comparative Fit Index } \\ \text { PNFI } & \text { Parsimonious Normed Fit Index } \\ \text { RFI } & \text { Relative Fit Index } \\ \text { RMR } & \text { Root Mean Squares Residuals } \\ \text { RMSEA } & \text { Root Mean Square Error of Approximation } \\ \text { ROS } & \text { Reactive Oxygen Species } \\ \text { SAM } & \text { S-Adenosyl-L-Methionine } \\ \text { SEM } & \text { Structure Equatation Modeling } \\ \text { SRMR } & \text { Standardized Root Mean Squares Residuals } \\ \text { SV } & \text { Sequence Variation } \\ \text { TCA } & \text { Tricarboxylic Acid Cycle } \\ \text { TCIV } & \text { Tissue Culture-Induced Variation } \\ & \end{array}$




\section{References}

1. Cistue, L.; Ramos, A.; Castillo, A.M. Influence of anther pretreatment and culture medium composition on the production of barley doubled haploids from model and low responding cultivars. Plant Cell Tissue Organ Cult. 1999, 55, 159-166. [CrossRef]

2. Sood, S.; Dwivedi, S. Doubled Haploid Platform: An Accelerated Breeding Approach for Crop Improvement. In Plant Biology and Biotechnology: Volume II: Plant Genomics and Biotechnology; Bahadur, B., Venkat Rajam, M., Sahijram, L., Krishnamurthy, K.V., Eds.; Springer: New Delhi, India, 2015; pp. 89-111. [CrossRef]

3. Huh, Y.S.; Lee, J.K.; Nam, S.Y. Effect of plant growth regulators and antioxidants on in vitro plant regeneration and callus induction from leaf explants of purple passion fruit (Passiflora edulis Sims). J. Plant Biotechnol. 2017, 44, 335-342. [CrossRef]

4. Yildiz, M. The Prerequisite of the Success in Plant Tissue Culture: High Frequency Shoot Regeneration. In Recent Advances in Plant In Vitro Culture; Leva, A., Ed.; IntechOpen: London, UK, 2012. [CrossRef]

5. Maraschin, S.F.; de Priester, W.; Spaink, H.P.; Wang, M. Androgenic switch: An example of plant embryogenesis from the male gametophyte perspective. J. Exp. Bot. 2005, 56, 1711-1726. [CrossRef] [PubMed]

6. Ito, H.; Gaubert, H.; Bucher, E.; Mirouze, M.; Vaillant, I.; Paszkowski, J. An siRNA pathway prevents transgenerational retrotransposition in plants subjected to stress. Nature 2011, 472, 115-119. [CrossRef]

7. Coronel, C.J.; González, A.I.; Ruiz, M.L.; Polanco, C. Analysis of somaclonal variation in transgenic and regenerated plants of Arabidopsis thaliana using methylation related metAFLP and TMD markers. Plant Cell Rep. 2018, 37, 137-152. [CrossRef]

8. Machczyńska, J.; Zimny, J.; Bednarek, P. Tissue culture-induced genetic and epigenetic variation in triticale $(\times$ Triticosecale spp. Wittmack ex A. Camus 1927) regenerants. Plant Mol. Biol. 2015, 89, 279-292. [CrossRef]

9. Orłowska, R.; Bednarek, P.T. Precise evaluation of tissue culture-induced variation during optimisation of in vitro regeneration regime in barley. Plant Mol. Biol. 2020, 103, 33-50. [CrossRef]

10. Polanco, C.; Ruiz, M.L. AFLP analysis of somaclonal variation in Arabidopsis thaliana regenerated plants. Plant Sci. 2002, 162, 817-824. [CrossRef]

11. Machczyńska, J.; Orłowska, R.; Mańkowski, D.R.; Zimny, J.; Bednarek, P.T. DNA methylation changes in triticale due to in vitro culture plant regeneration and consecutive reproduction. Plant Cell Tissue Organ Cult. 2014, 119, 289-299. [CrossRef]

12. Orłowska, R.; Machczyńska, J.; Oleszczuk, S.; Zimny, J.; Bednarek, P.T. DNA methylation changes and TE activity induced in tissue cultures of barley (Hordeum vulgare L.). J. Biol. Res. 2016, 23, 19. [CrossRef]

13. Orłowska, R.; Pachota, K.A.; Dynkowska, W.M.; Niedziela, A.; Bednarek, P.T. Androgenic-Induced Transposable Elements Dependent Sequence Variation in Barley. Int. J. Mol. Sci. 2021, 22, 6783. [CrossRef]

14. Rodríguez-Serrano, M.; Bárány, I.; Prem, D.; Coronado, M.-J.; Risueño, M.C.; Testillano, P.S. NO, ROS, and cell death associated with caspase-like activity increase in stress-induced microspore embryogenesis of barley. J. Exp. Bot. 2012, 63, $2007-2024$. [CrossRef]

15. Foyer, C.H.; Noctor, G. Redox Homeostasis and Antioxidant Signaling: A Metabolic Interface between Stress Perception and Physiological Responses. Plant Cell 2005, 17, 1866-1875. [CrossRef] [PubMed]

16. Das, K.; Roychoudhury, A. Reactive oxygen species (ROS) and response of antioxidants as ROS-scavengers during environmental stress in plants. Front. Environ. Sci. 2014, 2, 53. [CrossRef]

17. Wani, S.H.; Kumar, V.; Shriram, V.; Sah, S.K. Phytohormones and their metabolic engineering for abiotic stress tolerance in crop plants. Crop J. 2016, 4, 162-176. [CrossRef]

18. Durgud, M.; Gupta, S.; Ivanov, I.; Omidbakhshfard, M.A.; Benina, M.; Alseekh, S.; Staykov, N.; Hauenstein, M.; Dijkwel, P.P.; Hörtensteiner, S.; et al. Molecular Mechanisms Preventing Senescence in Response to Prolonged Darkness in a DesiccationTolerant Plant. Plant Physiol. 2018, 177, 1319-1338. [CrossRef] [PubMed]

19. Kunz, H.H.; Scharnewski, M.; Feussner, K.; Feussner, I.; Flügge, U.I.; Fulda, M.; Gierth, M. The ABC transporter PXA1 and peroxisomal beta-oxidation are vital for metabolism in mature leaves of Arabidopsis during extended darkness. Plant Cell 2009, 21, 2733-2749. [CrossRef] [PubMed]

20. Avin-Wittenberg, T.; Bajdzienko, K.; Wittenberg, G.; Alseekh, S.; Tohge, T.; Bock, R.; Giavalisco, P.; Fernie, A.R. Global analysis of the role of autophagy in cellular metabolism and energy homeostasis in Arabidopsis seedlings under carbon starvation. Plant Cell 2015, 27, 306-322. [CrossRef]

21. Nemeth, C.; Freeman, J.; Jones, H.D.; Sparks, C.; Pellny, T.K.; Wilkinson, M.D.; Dunwell, J.; Andersson, A.A.M.; Åman, P.; Guillon, F.; et al. Down-regulation of the CSLF6 gene results in decreased $(1,3 ; 1,4)$-beta-D-glucan in endosperm of wheat. Plant Physiol. 2010, 152, 1209-1218. [CrossRef] [PubMed]

22. Parra-Vega, V.; Corral-Martínez, P.; Rivas-Sendra, A.; Seguí-Simarro, J.M. Induction of Embryogenesis in Brassica Napus Microspores Produces a Callosic Subintinal Layer and Abnormal Cell Walls with Altered Levels of Callose and Cellulose. Front. Plant Sci. 2015, 6, 1018. [CrossRef]

23. Li, D.; Calderone, R. Exploiting mitochondria as targets for the development of new antifungals. Virulence 2017, 8, 159-168. [CrossRef] [PubMed]

24. Roulin, S.; Buchala, A.J.; Fincher, G.B. Induction of $(1 \rightarrow 3,1 \rightarrow 4)$ - $\beta$-D-glucan hydrolases in leaves of dark-incubated barley seedlings. Planta 2002, 215, 51-59. [CrossRef] [PubMed]

25. Sima, P.; Richter, J.; Vetvicka, V. Glucans as New Anticancer Agents. Anticancer. Res. 2019, 39, 3373-3378. [CrossRef] [PubMed]

26. Able, A.J.; Sutherland, M.W.; Guest, D.I. Production of reactive oxygen species during non-specific elicitation, non-host resistance and field resistance expression in cultured tobacco cells. Funct. Plant Biol. 2003, 30, 91-99. [CrossRef] [PubMed] 
27. Toro, G.; Pinto, M. Plant respiration under low oxygen. Chil. J. Agric. Res. 2015, 75, 57-70. [CrossRef]

28. Printz, B.; Lutts, S.; Hausman, J.-F.; Sergeant, K. Copper Trafficking in Plants and Its Implication on Cell Wall Dynamics. Front. Plant Sci. 2016, 7, 601. [CrossRef] [PubMed]

29. Ravet, K.; Pilon, M. Copper and Iron Homeostasis in Plants: The Challenges of Oxidative Stress. Antioxid. Redox Signal 2013, 19, 919-932. [CrossRef] [PubMed]

30. Pádua, M.; Cavaco, A.M.; Aubert, S.; Bligny, R.; Casimiro, A. Effects of copper on the photosynthesis of intact chloroplasts: Interaction with manganese. Physiol. Plant. 2010, 138, 301-311. [CrossRef]

31. Tan, Y.-F.; O'Toole, N.; Taylor, N.L.; Millar, A.H. Divalent metal ions in plant mitochondria and their role in interactions with proteins and oxidative stress-induced damage to respiratory function. Plant Physiol. 2010, 152, 747-761. [CrossRef] [PubMed]

32. Hirayama, T.; Alonso, J.M. Ethylene Captures a Metal! Metal Ions Are Involved in Ethylene Perception and Signal Transduction. Plant Cell Physiol. 2000, 41, 548-555. [CrossRef]

33. Bowler, C.; Montagu, M.V.; Inze, D. Superoxide dismutase and stress tolerance. Annu. Rev. Plant Biol. 1992, 43, 83-116. [CrossRef]

34. Lauer, M.M.; de Oliveira, C.B.; Yano, N.L.I.; Bianchini, A. Copper effects on key metabolic enzymes and mitochondrial membrane potential in gills of the estuarine crab Neohelice granulata at different salinities. Comp. Biochem. Physiol. Part C Toxicol. Pharmacol. 2012, 156, 140-147. [CrossRef]

35. Cong, W.; Miao, Y.; Xu, L.; Zhang, Y.; Yuan, C.; Wang, J.; Zhuang, T.; Lin, X.; Jiang, L.; Wang, N.; et al. Transgenerational memory of gene expression changes induced by heavy metal stress in rice (Oryza sativa L.). BMC Plant Biol. 2019, 19, 282. [CrossRef]

36. Svirshchevskaya, A.M.; Bormotov, V.E. Characteristic property of regeneration under gynogenesis of sugar-beet. Doklady Akademii Nauk Belarusi 1994, 38, 57-59.

37. Trifonova, A.; Madsen, S.; Olesen, A. Agrobacterium-mediated transgene delivery and integration into barley under a range of in vitro culture conditions. Plant Sci. 2001, 161, 871-880. [CrossRef]

38. Caredda, S.; Clément, C. Androgenesis and albinism in Poaceae: Influence of genotype and carbohydrates. In Anther and Pollen; Springer: Berlin/Heidelberg, Germany, 1999; pp. 211-228.

39. Yao, J.L.; Cohen, D. Multiple gene control of plastome-genome incompatibility and plastid DNA inheritance in interspecific hybrids of Zantedeschia. Theor. Appl. Genet. 2000, 101, 400-406. [CrossRef]

40. Makowska, K.; Oleszczuk, S. Albinism in barley androgenesis. Plant Cell Rep. 2014, 33, 385-392. [CrossRef]

41. Cohu, C.M.; Pilon, M. Cell Biology of Copper. In Cell Biology of Metals and Nutrients; Hell, R., Mendel, R.-R., Eds.; Springer: Berlin/Heidelberg, Germany, 2010; pp. 55-74. [CrossRef]

42. Jacquard, C.; Nolin, F.; Hecart, C.; Grauda, D.; Rashal, I.; Dhondt-Cordelier, S.; Sangwan, R.S.; Devaux, P.; Mazeyrat-Gourbeyre, F.; Clement, C. Microspore embryogenesis and programmed cell death in barley: Effects of copper on albinism in recalcitrant cultivars. Plant Cell Rep. 2009, 28, 1329-1339. [CrossRef]

43. Orłowska, R.; Pachota, K.A.; Machczyńska, J.; Niedziela, A.; Makowska, K.; Zimny, J.; Bednarek, P.T. Improvement of anther cultures conditions using the Taguchi method in three cereal crops. Electron. J. Biotechnol. 2020, 43, 8-15. [CrossRef]

44. Puchkova, L.V.; Broggini, M.; Polishchuk, E.V.; Ilyechova, E.Y.; Polishchuk, R.S. Silver Ions as a Tool for Understanding Different Aspects of Copper Metabolism. Nutrients 2019, 11, 1364. [CrossRef]

45. Costa, C.S.; Ronconi, J.V.V.; Daufenbach, J.F.; Gonçalves, C.L.; Rezin, G.T.; Streck, E.L.; da Silva Paula, M.M. In vitro effects of silver nanoparticles on the mitochondrial respiratory chain. Mol. Cell. Biochem. 2010, 342, 51-56. [CrossRef] [PubMed]

46. McDaniel, B.K.; Binder, B.M. Ethylene Receptor 1 (ETR1) Is Sufficient and Has the Predominant Role in Mediating Inhibition of Ethylene Responses by Silver in Arabidopsis thaliana. J. Biol. Chem. 2012, 287, 26094-26103. [CrossRef] [PubMed]

47. Rodríguez, F.I.; Esch, J.J.; Hall, A.E.; Binder, B.M.; Schaller, G.E.; Bleecker, A.B. A copper cofactor for the ethylene receptor ETR1 from Arabidopsis. Science 1999, 283, 996-998. [CrossRef] [PubMed]

48. Bednarek, P.T.; Orłowska, R. CG Demethylation Leads to Sequence Mutations in an Anther Culture of Barley Due to the Presence of $\mathrm{Cu}, \mathrm{Ag}$ Ions in the Medium and Culture Time. Int. J. Mol. Sci. 2020, 21, 4401. [CrossRef] [PubMed]

49. Baker, M.J.; Trevisan, J.; Bassan, P.; Bhargava, R.; Butler, H.J.; Dorling, K.M.; Fielden, P.R.; Fogarty, S.W.; Fullwood, N.J.; Heys, K.A.; et al. Using Fourier transform IR spectroscopy to analyze biological materials. Nat. Protoc. 2014, 9, 1771-1791. [CrossRef] [PubMed]

50. Bednarek, P.T.; Zebrowski, J.; Orłowska, R. Exploring the Biochemical Origin of DNA Sequence Variation in Barley Plants Regenerated via in Vitro Anther Culture. Int. J. Mol. Sci. 2020, 21, 5770. [CrossRef]

51. Legner, N.; Meinen, C.; Rauber, R. Root Differentiation of Agricultural Plant Cultivars and Proveniences Using FTIR Spectroscopy. Front. Plant Sci. 2018, 9, 748. [CrossRef]

52. Bureau, S.; Cozzolino, D.; Clark, C.J. Contributions of Fourier-transform mid infrared (FT-MIR) spectroscopy to the study of fruit and vegetables: A review. Postharvest Biol. Technol. 2019, 148, 1-14. [CrossRef]

53. Rana, R.; Herz, K.; Bruelheide, H.; Dietz, S.; Haider, S.; Jandt, U.; Pena, R. Leaf Attenuated Total Reflection Fourier Transform Infrared (ATR-FTIR) biochemical profile of grassland plant species related to land-use intensity. Ecol. Indic. 2018, 84, 803-810. [CrossRef]

54. Pereira, W.J.; Pappas, M.d.C.R.; Grattapaglia, D.; Pappas, G.J., Jr. A cost-effective approach to DNA methylation detection by Methyl Sensitive DArT sequencing. PLoS ONE 2020, 15, e0233800. [CrossRef] 
55. Hayes, A.F. Introduction to Mediation, Moderation, and Conditional Process Analysis. A Regression Bases Approach; A Division of Guilford Publications, Inc.: New York, NY, USA, 2018; p. 507.

56. Bednarek, P.T.; Orłowska, R. Time of In Vitro Anther Culture May Moderate Action of Copper and Silver Ions that Affect the Relationship between DNA Methylation Change and the Yield of Barley Green Regenerants. Plants 2020, 9, 1064. [CrossRef] [PubMed]

57. Yang, S.F.; Hoffman, N.E. Ethylene Biosynthesis and its Regulation in Higher Plants. Annu. Rev. Plant Physiol. 1984, 35, 155-189. [CrossRef]

58. Sauter, M.; Moffatt, B.; Saechao, M.C.; Hell, R.; Wirtz, M. Methionine salvage and S-adenosylmethionine: Essential links between sulfur, ethylene and polyamine biosynthesis. Biochem. J. 2013, 451, 145-154. [CrossRef]

59. Kende, H. Ethylene Biosynthesis. Annu. Rev. Plant Physiol. Plant Mol. Biol. 1993, 44, 283-307. [CrossRef]

60. Lee, D.H.; O'Connor, T.R.; Pfeifer, G.P. Oxidative DNA damage induced by copper and hydrogen peroxide promotes CG->TT tandem mutations at methylated CpG dinucleotides in nucleotide excision repair-deficient cells. Nucleic Acids Res. 2002, 30, 3566-3573. [CrossRef]

61. McDonald, R.P. A simple comprehensive model for the analysis of covariance structures. Br. J. Math. Stat. Psychol. 1978, 31, 59-72. [CrossRef]

62. Jöreskog, K.G. Structural equation models in the social sciences: Specification, estimation and testing. In Applications in Statistics; Krishnaiah, P.R., Ed.; Applications in Statistics: New York, NY, USA, 1977; pp. 265-287.

63. Shipley, B. Cause and Correlation in Biology: A User's Guide to Path Analysis, Structural Equations and Causal Inference; Cambridge University Press: Cambridge, UK, 2000. [CrossRef]

64. Kozak, M.; Kang, M.S. Note on modern path analysis in application to crop science. Commun. Biometry Crop Sci. 2006, 1, 32-34.

65. Lamb, E.G.; Shirtliffe, S.J.; May, W.E. Structural equation modeling in the plant sciences: An example using yield components in oat. Can. J. Plant Sci. 2011, 91, 603-619. [CrossRef]

66. Arbuckle, J.L. Amos; Version 23.0; IBM SPSS: Chicago, IL, USA, 2014.

67. Levenberg, K. A method for the solution of certain non linear problems in least squares. Q. Appl. Math. 1944, 2, 164-168. [CrossRef]

68. Madsen, K.; Nielsen, H.B.; Tingleff, O. Methods for Non-Linear Least Squares Problems. Informatics and Mathematical Modeling; Technical University of Denmark: Lyngby, Denmark, 2004.

69. Marquardt, D.W. An Algorithm for Least-Squares Estimation of Nonlinear Parameters. J. Soc. Ind. Appl. Math. 1963, 11, 431-441. [CrossRef]

70. Taboga, M. Lectures on Probability Theory and Mathematical Statistics; CreateSpace Independent Publishing Platform: North Charleston, SC, USA, 2012.

71. Kenny, D.A. Measuring Model Fit. Available online: http:/ / davidakenny.net/cm/fit.htm (accessed on 12 October 2019).

72. Bentler, P.M.; Bonett, D.G. Significance tests and goodness-of-fit in the analysis of covariance structures. Psychol. Bull. 1980, 88, 588-600. [CrossRef]

73. Kenny, D.A.; McCoach, D.B. Effect of the Number of Variables on Measures of Fit in Structural Equation Modeling. Struct. Equ. Model. A Multidiscip. J. 2003, 10, 333-351. [CrossRef]

74. MacCallum, R.C. Working with imperfect models. Multivar. Behav. Res. 2003, 1, 13-149.

75. Ho, R. Handbook of Univariate and Multivariate Data Analysis and Interpretation with SPSS; Central Queensland University: Rockhampton, Australia, 2006.

76. Williams, L.J.; Holahan, P.J. Parsimony-based fit indices for multiple-indicator models: Do they work? Struct. Equ. Model. A Multidiscip. J. 1994, 1, 161-189. [CrossRef]

77. Hu, L.-T.; Bentler, P.M. Fit indices in covariance structure modeling: Sensitivity to underparameterized model misspecification. Psychol. Methods 1998, 3, 424-453. [CrossRef]

78. Hu, L.-T.; Bentler, P.M. Cutoff criteria for fit indices in covariance structure analysis: Conventional criteria versus new alternatives. Struct. Equ. Model. 1999, 6, 1-55. [CrossRef]

79. Mulaik, S.A.; James, L.R.; Van Alstine, J.; Bennett, N.; Lind, S.; Stilwell, C.D. Evaluation of goodness-of-fit indices for structural equation models. Psychol. Bull. 1989, 105, 430-445. [CrossRef]

80. MacCallum, R.C.; Browne, M.W.; Sugawara, H.M. Power analysis and determination of sample size for covariance structure modeling. Psychol. Methods 1996, 1, 130-149. [CrossRef]

81. Mansilla, N.; Racca, S.; Gras, D.E.; Gonzalez, D.H.; Welchen, E. The Complexity of Mitochondrial Complex IV: An Update of Cytochrome c Oxidase Biogenesis in Plants. Int. J. Mol. Sci. 2018, 19, 662. [CrossRef]

82. Horn, D.; Barrientos, A. Mitochondrial copper metabolism and delivery to cytochrome c oxidase. IUBMB Life 2008, 60, 421-429. [CrossRef]

83. Zhang, Y.; Fernie, A.R. On the role of the tricarboxylic acid cycle in plant productivity. J. Integr. Plant Biol. 2018, 60, 1199-1216. [CrossRef] [PubMed]

84. Touraev, A.; Pfosser, M.; Heberle-Bors, E. The microspore: A haploid multipurpose cell. Adv. Bot. Res. 2001, 35, 53-109.

85. Moffatt, B.A.; Weretilnyk, E.A. Sustaining S-adenosyl-l-methionine-dependent methyltransferase activity in plant cells. Physiol. Plant. 2001, 113, 435-442. [CrossRef] 
86. Ogawa, T.; Tsubakiyama, R.; Kanai, M.; Koyama, T.; Fujii, T.; Iefuji, H.; Soga, T.; Kume, K.; Miyakawa, T.; Hirata, D.; et al. Stimulating S-adenosyl-1-methionine synthesis extends lifespan via activation of AMPK. Proc. Natl. Acad. Sci. USA 2016, 113, 11913-11918. [CrossRef]

87. Powell, W.; Thomas, W.T.B.; Baird, E.; Lawrence, P.; Booth, A.; Harrower, B.; McNicol, J.W.; Waugh, R. Analysis of quantitative traits in barley by the use of Amplified Fragment Length Polymorphisms. Heredity 1997, 79, 48-59. [CrossRef] 